\title{
Modelling of LPG Ship Distribution in Western of Indonesia using Discrete Simulation Method
}

\author{
Trika Pitana ${ }^{1}$, R.O Saut Gurning ${ }^{2}$, and Fauzan Fikri ${ }^{3}$
}

\begin{abstract}
Energy Outlook Indonesia issued by the National Energy Board, mentioned the demand of LPG every year continues to rise, and there is a regions has high increased still at western part of Indonesia, precisely in the Sumatra and Java Island. Because of that, so effort to necessary an assesment for remake case study on the distribution pattern of vessels with the techincal data on the loading port and discharging port. The data has affecting distribution pattern of vessels, will be used to replicate previously existing transport system currently operated by using discrete simulation method, evaluated, and scenario building improvements to variations number and size of the capacity of vessels to get distribution pattern of effective and efficient. The result of this research obtained scenario capable to meet the demands of each destination terminal port with a case study during the next 5 years and also which has a vesseles operating expenses are the most economical.
\end{abstract}

Keywords—demand of LPG, discrete event simulation, LPG vessel distribution

\section{INTRODUCTION}

S ince the government issued a policy conversion of kerosene to gas [2], the demand of LPG every year continues to rise, especially LPG demand of the household sector This problem shown by the data of Indonesia Energy Outlook 2014 issued by the National Energy Board [1].. Base from the data, mentioned that each year its LPG demand is increasing, and also mentioned the need for energy is proportional to the factor of development itself [8].
So far the existing development in Indonesia is still leaning on the western of Indonesian regions, the data also proved that in the Sumatra Island has increased the demands of its 3\% [7] every year and Java has increased of $3.9 \%$ every year [6]. Because of the increasing demands LPG, so required a review of the pattern of distribution of LPG vessels [9], which will be the main mode of transportation for cargo of LPG.

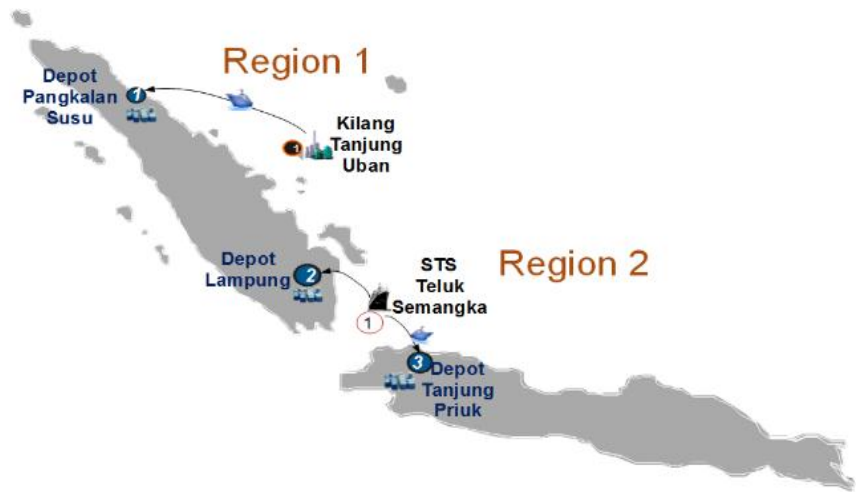

Figure. 1. Storage and supply LPG PT. Pertamina West Indonesia

Trika Pitana, Departement of Marine Engineering, Institut Technology Sepuluh Nopember, Surabaya 601111, Indonesia. E-mail: pitanatrika@gmail.com

R.O Saut Gurning, Departement of Marine Engineering, Institut Technology Sepuluh Nopember, Surabaya 601111, Indonesia. E-mail: sautgurning2@gmail.com

Fauzan Fikri, Departement of Marine Engineering, Institut Technology Sepuluh Nopember, Surabaya 601111, Indonesia.

E-mail:fauzanfikri15@gmail.com 
Determination of the number and capacity of the vessels is right so difficult, because there are several variables to be considered [4], namely the ship's speed when carrying cargo or not, when the speed of the ship on the high seas or close to the port, as well as the number of fluctuating demand. With such framework, a simulation modeling the distribution of LPG Vessel PT. Pertamina, which correspond needed in order to represent the real system of the distribution pattern of LPG vessels PT. Pertamina in West Indonesia. The system will be modeled on the process is to evaluate the charge transport LPG ongoing route cruise [5] :

a) Kilang Tanjung Uban - Depot Pangkalan Susu.

b) STS Teluk Semangka - Depot Lampung.

c) STS Teluk Semangka - Depot Tanjung Priuk

\section{METHOD}

In making this research, of course, require a structured process, so that in the future the work will be more focused and easier. The overall step of the research methods has a total 6 steps start with identifying the problem are occurred to determine what the problem formulation must be taken. Formulation of the problem is an early stage in the implementation of the research. The next step is Literature Review come out with literature study from the previous research and fundamental of theories from book, journal, internet and thesis. The second step is to collect and process data from record activities that affect the distribution pattern of the ship. This data collection in accordance with the limits defined problem that is the result of the identification loading port, discharging port, and LPG Ship. The third step is to build a model [3]. The function of this model is representation of existing condisitons. Next, the fourth step is verification and validation of models. The fifth is building a simulation scenario, to provide options to be considered for evalution. The last step is analysis and interpretation of model results.

\section{RESULTS AND DISCUSSION}

\section{A. Collecting and Processing Data}

In the discussion of the present study will be presented an analysis of the overall result, but to explain the steps the same because each scheme depot, then the discussion this time will only take a sample to scheme Depot Lampung. The initial step in this research is to collect data from record activities that affect the distribution pattern of the ship. This data collection in accordance with the limits defined problem that is the result of the identification of the variables listed below, among others

\section{Identification Loading Port}

a. Kilang Tanjung Uban.

b. STS Teluk Semangka.

In the process of identification loading port, there are some data that should be known, among others :

1. Position and Location Loading port.

2. The capacity of LPG storage tanks.

3. Record Data Pump Speed Ports / Terminals Loading.

4. Record Data Waiting Time Ports / Terminal Loading.

\section{Identifications Discharging Port}
a. Depot Pangkalan Susu.
b. Depot Lampung.
c. Depot Tanjung Priuk.

In discharging port identification process, there are some data that should be known, among others :

1. Position and Location discharging port.

2. The capacity LPG storage tanks.

3. Record Data Pump Speed Ports / Terminals discharging.

4. Record Data Waiting Time Ports / Terminals Discharging.

\section{Identification of LPG Ships}

$\begin{array}{llll}\text { a } & \text { Arjuna } & \text { i } & \text { Gas Arimbi } \\ \text { b } & \text { Gas Patra 1 } & \text { j } & \text { Ambalat } \\ \text { c } & \text { Nusa Bintang } & \text { k } & \text { Gas Artemis } \\ \text { d } & \text { Gas Soechi } & \text { 1 } & \text { Navigator Mariner } \\ \text { e } & \text { Gas Attaka } & \text { m } & \text { Widuri } \\ \text { f } & \text { Gas Natuna } & \text { n } & \text { Apoda } \\ \text { g } & \text { Eleanor } & \text { o } & \text { Raggiana } \\ \text { h } & \text { Gas Arar } & \text { p } & \text { Pertamina Gas 1 }\end{array}$

In the process of identification of LPG vessels, there are some data that should be known, among others :

1. Record the speed of the ship when laden and ballast.

2. Record speed vessel on the high seas at the moment as it approached the port terminal.

3. Record the pump speed boat.

4. Dead Weight Tonnage (DWT).

5. Gross Register Tonnage (GRT).

6. Bunker Consumption at Sea. a. In Laden. b. Ballast.

7. Bunker Consumption in Port. a. Loading. b. Discharging.

8. Charter Rate.

9. Port Charge. 
TABLE 1.

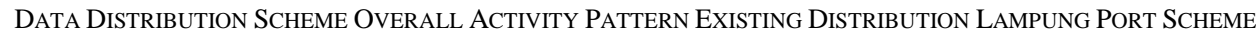

\begin{tabular}{|c|c|c|}
\hline No & Activity & Distribution expression \\
\hline 1 & Demand 1 year Depot Lampung & TRIA(-0.001, 483, 592) \\
\hline 2 & Demand 5 years Depot Lampung & $\operatorname{NORM}(442,181))$ \\
\hline 3 & Record data speed pump STS Teluk Semangka & TRIA $(110,261,1.02 \mathrm{e}+003))$ \\
\hline 4 & Record data waiting time loading port STS Teluk Semangka & $\operatorname{NORM}(6,0.6)$ \\
\hline 5 & Record data ship speed Asian Gas (Laden) & $\operatorname{NORM}(10.7,3.15)$ \\
\hline 6 & Record data ship speed Asian Gas (Ballast) & $\operatorname{NORM}(11.4,2.88)$ \\
\hline 7 & Record data ship speed Asian Gas Mendekati Pelabuhan & $\operatorname{UNIF}(2,6)$ \\
\hline 8 & Record data speed pump of ship Asian Gas & TRIA $(45,116,215)$ \\
\hline 9 & Record data ship speed Eleanor (Laden) & $\operatorname{NORM}(11.4,2.88)$ \\
\hline 10 & Record data ship speed Eleanor (Ballast) & TRIA $(9,10,19)$ \\
\hline 11 & Record data ship speed Eleanor near port & $\operatorname{UNIF}(2,6)$ \\
\hline 12 & Record data speed pump of ship & $\operatorname{NORM}(136,30)$ \\
\hline
\end{tabular}

All data collection identified in this study originated from PT. Pertamina Shipping. From the data that affect the distribution pattern will ship in the recapitulation to get input values for the model. The input value is in the form of distribution of the data from the data records which were obtained by collecting the results of all the activity that occurred in 2015. Record data is then processed by the analyzer input from software to get value distribution with consideration of the smallest squareerror. The results of the data distribution can be seen in Table 1, which explains the activity of the scheme depot, and in this case the sample is taken depot Lampung.

\section{B. Design Simulation Model}

The conceptual model was made before the design of the model with the software, so that the logic-logic modeling is not until something goes wrong. The conceptual model can be seen in Figure 2 .

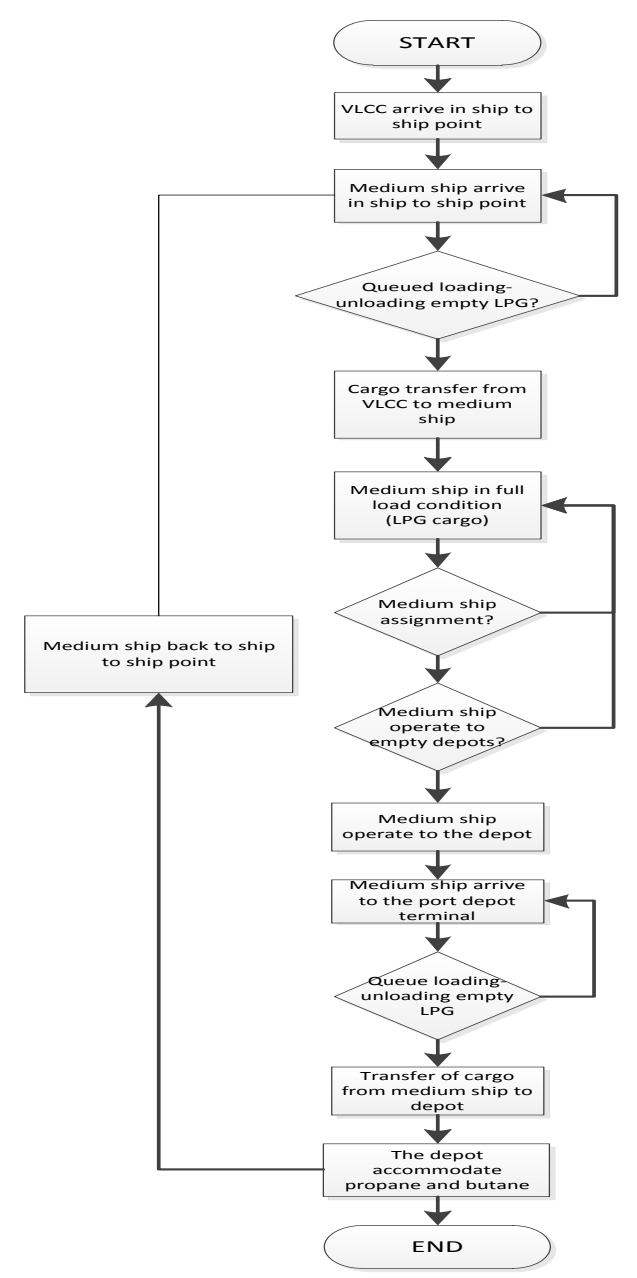

Figure. 1. Conceptual model Lampung port scheme 
With basic conceptual model that has been made and the overall data distribution scheme of distribution patterns of activity of LPG vessels PT. Pertamina scheme of Depot Teluk Semangka, then made a model by using software. Examples of the model can be seen in Figure 3.

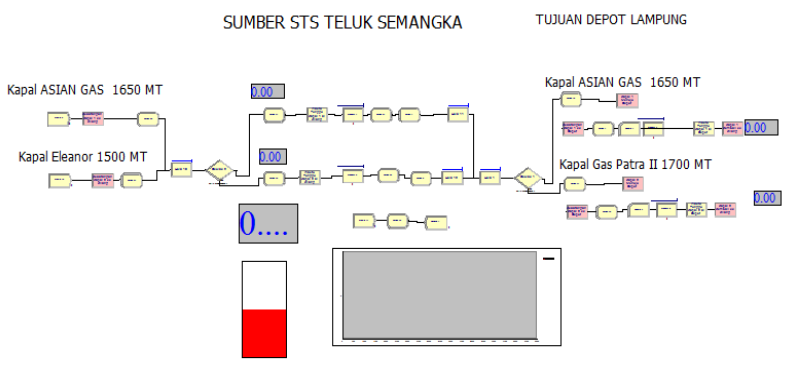

Figure. 2. Existing model Lampung port scheme

\section{Verification and Validation Simulation Model}

Verification of this research is done by ensuring that the simulation model runs as expected and ensure that the model is free of error.
With the help of software, the model can be seen free from error with the mark as shown in Figure 4.

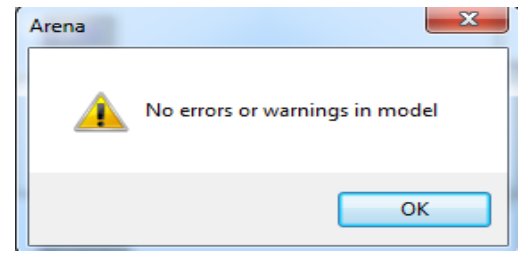

Figure. 4. Result of verification model Lampung port scheme

Having declared verify the model, the next step is validation. The validation process will be carried out on the model is to compare the output data from the system on models with output data from the real system.
Benchmarking was performed significance level of the similarity of the two -time data using t-test 2 -sample . Data output from both the model and the real system in Scheme Depot Lampung in Table 2.

TABLE 2.

RESULF OF OUTPUT MODEL AND REAL SYSTEM

\begin{tabular}{ccc}
\hline Month & Existing & Simulation Results \\
\hline 1 & 35,161 & 31950 \\
\hline 2 & 25,666 & 31950 \\
\hline 3 & 31221 & 29600 \\
\hline 4 & 31084 & 29600 \\
\hline 5 & 32,296 & 29600 \\
\hline 6 & 29,582 & 31550 \\
\hline 7 & 34257 & 29600 \\
\hline 8 & 32330 & 29600 \\
\hline 9 & 29266 & 33350 \\
\hline 10 & 35118 & 29600 \\
\hline 11 & 31527 & 27900 \\
\hline 12 & 33722 & 31000 \\
\hline Mean & 31,769 & 30,442 \\
\hline Stdv. & 2737.632482 & 1515.350744 \\
\hline variansi & 7494631.606 & 2296287.879 \\
\hline $\mathrm{N}$ & 12 & 12 \\
\hline $\mathrm{n}-1$ & 11 & 11
\end{tabular}

The method used for validation testing of this model is the method of Welch Confidence Interval. Where: hypothesis:

$$
\begin{array}{r}
\mathrm{H}_{0}=\mu 1-\mu 2=0 \\
\mathrm{H} 1=\mu 1-\mu 2 \neq 0 \\
\alpha=0,0
\end{array}
$$

$$
\begin{aligned}
& d f=\frac{\left(\frac{s 1^{2}}{n 1}+\frac{s 2^{2}}{n 2}\right)^{2}}{\frac{\left(\frac{n 1^{2}}{n 1}\right)^{2}}{n 1-1}+\frac{\left(\frac{n 2^{2}}{n_{2}}\right)^{2}}{n 2-1}} \\
& \mathrm{D} f=17,16 \sim 17
\end{aligned}
$$

The result is , $t_{d f_{d} / 2}=2,11$ 


$$
\begin{aligned}
& h w=t_{d f, a / 2} \sqrt{\frac{s 1^{2}}{n 1}+\frac{s 2^{2}}{n 2}} \\
& h w=1667.67 \\
& \text { So : } \\
& {[(x 1-x 2)-h w \leq \mu 1-\mu 2 \leq(x 1-x 2)+h w]} \\
& -340 \leq \mu 1-\mu 2 \leq 2995
\end{aligned}
$$

If the value 0 is in the range $\mu 1-\mu 2$, it can be concluded that there is no significant difference between the results of the simulation with the real condition of the system, and that means the results of the simulation can be said to be valid.

\section{Determine Number Replication}

To reduce the variance of the simulation should be done $\mathrm{n}$ times replication. To get the value of $\mathrm{n}$ it is necessary to replication.

$$
\begin{aligned}
& \mathrm{N} \quad=12 \text { (initial replication) } \\
& \mathrm{n}-1 \quad=11 \\
& \text { confidence interval } \quad=95 \% \\
& \alpha \\
& =1-95 \%=5 \%=0.05
\end{aligned}
$$

$$
t_{n-1, a / 2}=2,201
$$

half width

$$
\begin{aligned}
& =\frac{t_{m-1, a / 2} x g}{\sqrt{n}} \\
& =962.81 \\
& =\text { half width } \\
& =\left(\frac{z_{m / 2} s 1}{\beta}\right)^{2}
\end{aligned}
$$

Betha $n$ ’

$$
\begin{aligned}
& =\left[\frac{1.65 \times 1515.4}{962.91}\right]^{2} \\
& =6.662 \approx 7
\end{aligned}
$$

From the above calculation results obtained simulating the amount of replication scheme for the distribution of LPG vessels Depot Lampung which is 7 times.

\section{E. Analysis and Interpretation of Model Result}

Issues raised in this research is an increased need for data-driven Energy Outlook Indonesia. As to meet the increasing needs of the case study next 5 years, the existing condition of the distribution pattern of the ship towards the depot to try to be re-examined or it is also necessary to build scenarios with consideration of improvements to meet increased demand as well as vessel operating costs are economical. There is also a

\begin{tabular}{|c|c|c|c|c|}
\hline $\begin{array}{l}\text { Number of } \\
\text { Replication }\end{array}$ & Ship name & $\begin{array}{c}\text { Capacity } \\
\text { (MT) }\end{array}$ & $\begin{array}{c}\text { Number of } \\
\text { Trip }\end{array}$ & Total of LPG \\
\hline \multirow{3}{*}{1} & Asian Gas & 1650 & 271 & 447150 \\
\hline & Eleanor & 1500 & 191 & 286500 \\
\hline & & Total & & 733650 \\
\hline \multirow{3}{*}{2} & Asian Gas & 1650 & 268 & 442200 \\
\hline & Eleanor & 1500 & 197 & 295500 \\
\hline & & Total & & 737700 \\
\hline \multirow{3}{*}{3} & Asian Gas & 1650 & 279 & 460350 \\
\hline & Eleanor & 1500 & 186 & 279000 \\
\hline & & Total & & 739350 \\
\hline \multirow{3}{*}{4} & Asian Gas & 1650 & 251 & 414150 \\
\hline & Eleanor & 1500 & 205 & 307500 \\
\hline & & Total & & 721650 \\
\hline \multirow{3}{*}{5} & Asian Gas & 1650 & 265 & 437250 \\
\hline & Eleanor & 1500 & 199 & 298500 \\
\hline & & Total & & 735750 \\
\hline \multirow{3}{*}{6} & Asian Gas & 1650 & 262 & 432300 \\
\hline & Eleanor & 1500 & 196 & 294000 \\
\hline & & Total & & 726300 \\
\hline \multirow{3}{*}{7} & Asian Gas & 1650 & 265 & 437250 \\
\hline & Eleanor & 1500 & 199 & 298500 \\
\hline & & Total & & 735750 \\
\hline
\end{tabular}
heavy foundation - technical heavy foundation used to build scenarios during the process of running, among others:

- Draught of Vessels $\leq$ Draught of Port.

- Cargo of LPG in Depot $\geq$ Safety Stock.

- Cargo of LPG in Depot $\leq$ Max. Capacity in Depot.

With case studies that have been mentioned, for the first time need to reexamine eksisiting conditions, and furthermore can also build scenarios pebaikan as required by considerations that have been determined . In the discussion this time to serve as an example, would raise the issue of Lampung Port scheme. Here are the results of running of the existing models Depot Lampung

TABLE 3.

RESUlt of EXISTING SimUlation LAMPUNG PORT SCHEME 


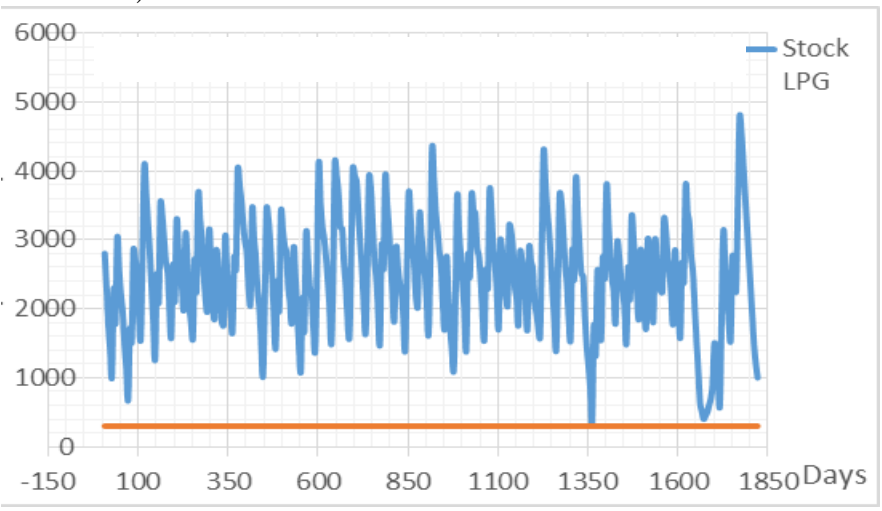

Figure. 5. Graphic Inventory Level stock existing LPG Lampung port scheme

In Figure 6 contained a chart that explains the inventory stock level where as the technical requirements of a distribution pattern is successful or not less than meets current safety stock that has been determined.

In Table 3 is an example of the results of running the simulation for 5 years in Lampung depot scheme, wherein the obtained amount from the table vessel trip . With the number of trips the vessel has been known, then akandiketahui the amount of cargo that can be supplied to a pattern of hasi distribisi summation calculation charge by the number of boat trips. So that by analyzing the table, it can be known whether the simulation result of a distribution pattern can meet the increasing needs of existing or not.

\section{Building a Simulation Scenario}

When the results of the existing condition not yet meet increased demand, or already meet but would look for an economical vessel operating expenses, it can be an option to build a repair scenario, where variations can be given that the size and number of vessels on duty in a distribution pattern. With these things will be given the assignment of the vessel (reorder point) will affect the number of trips on a ship distribution pattern.

\section{F. Analysis Ship Operation Cost}

From the results of the modeling that has been done, get some of the scenarios that were able to meet the increasing needs of LPG. In this study, the authors will count only vessel operating costs of a scenario that meets any of the problems posed. Analysis of these costs consist of:

1. Bunkering consumption,

2. Port charges.

3. Charter rate.

\section{Bunkering Consumption}

In the calculation of vessel fuel costs in this study are the specification of fuel use HFO, MDO, HSD in the position of the boat is sea time (laden and ballast), port time (loading and unloading). More as an example can be seen in Table 4.

Once known fuel consumption per day, it takes running simulation for 5 years for the total time how long the ship when the sea conditions time (laden and ballast), port time (loading and unloading). More in Table 5.

TABLE. 4.

FUEL CONSUMPTION PER DAY LAMPUNG PORT SCHEME

\begin{tabular}{|c|c|c|c|c|c|c|c|c|}
\hline \multirow{4}{*}{ Scenario } & \multirow{4}{*}{ No. } & \multirow{4}{*}{ Ship name } & \multicolumn{6}{|c|}{ Bunker consumption (MT/day) } \\
\hline & & & \multicolumn{6}{|c|}{ Port } \\
\hline & & & \multicolumn{3}{|c|}{ Loading } & \multicolumn{3}{|c|}{ Discharge } \\
\hline & & & $\mathrm{MFO}$ & MDO & HSD & MFO & MDO & HSD \\
\hline \multirow{3}{*}{3} & 1 & ASIAN GAS & 0.00 & 0.64 & 0.00 & 0.00 & 1.54 & 0.00 \\
\hline & 2 & GAS PATRA 1 & 0.00 & 0.70 & 0.00 & 0.00 & 1.20 & 0.00 \\
\hline & 3 & GAS ARAR & 0.00 & 0.70 & 0.00 & 0.00 & 1.20 & 0.00 \\
\hline
\end{tabular}

TABLE 5.

Total Operation Time ShIPs OVER 5 YeARs LAMPung PoRT Scheme

\begin{tabular}{|c|c|c|c|c|c|c|}
\hline \multirow{3}{*}{ Scenario } & \multirow{3}{*}{ No. } & \multirow{3}{*}{ Ship name } & \multicolumn{4}{|c|}{ Time (day) } \\
\hline & & & \multirow{2}{*}{ Laden } & \multirow{2}{*}{ Ballast } & \multicolumn{2}{|c|}{ Port } \\
\hline & & & & & Loading & Discharge \\
\hline \multirow{3}{*}{3} & 1 & ASIAN GAS & 384 & 361 & 87 & 112 \\
\hline & 2 & GAS PATRA 1 & 219 & 202 & 61 & 77 \\
\hline & 3 & GAS ARAR & 289 & 299 & 77 & 92 \\
\hline
\end{tabular}


The next step is to convert the cost per fuel type in Table 6.
After all you have, then pour down for 5 years what is the cost of fuel needed, more in Table 6.

TABLE 6.

COST FUEL SHIP ACCORDANCE KIND Fuel oil price

\begin{tabular}{ccc}
\hline & Fuel oil price & \\
\hline Bunker & Bunker RKAP 2016 (USD/MT) & Bunker RKAP 2016 (USD/MT) \\
\hline MFO & 316.61 & IDR 4,400,857.20 \\
\hline MDO & 457.04 & IDR 6,352,792.37 \\
\hline HSD & 479.90 & IDR 6,670,674.94 \\
\hline
\end{tabular}

TABLE 7.

TOtAl Cost OF FUEL SHIP LAMPUNG PORT SCHEME

\begin{tabular}{cccc}
\hline Scenario & No. & Ship name & Total cost \\
\hline \multirow{3}{*}{3} & 1 & ASIAN GAS & IDR 23,619,435,516.70 \\
\cline { 2 - 4 } & 2 & GAS PATRA 1 & IDR 24,892,555,592.77 \\
\cline { 2 - 4 } & 3 & GAS ARAR & IDR 25,628,991,695.11 \\
\hline
\end{tabular}

\section{Charter Rate}

Boat rental fees referred to in the study of its time charter, so it is seen that the total time of use of the vessel in which the fee already includes crews so PT.Pertamina receive and assign the ship is ready to operate. Calculation of the cost of renting these boats will need to know in advance how the rental price per day his ship, and then added together for a total time previously determined for each of the vessels in operation. Here are the results of the calculation of costs in running hire during the year can be seen in Table 8 .

\section{Port Charges}

The calculation of the cost of a ship docking fees earned from ship cost for one lean multiplied by the number of frequency of arrival of the vessel in both the loading and discharging ports port.Hasil of ship docked cost calculation can be seen in Table 9.

After analyzing the cost of each ship, then by way of summing everything can be obtained total vessel operating expenses for repair scenarios that have previously been constructed. More able to Lampung depot scheme as an example can be seen in Table 10 .

TABLE 8.

Total Cost Calculation CHARTER Rate LAMPUng Port SCHEME

\begin{tabular}{|c|c|c|c|c|c|c|}
\hline \multirow{2}{*}{ Scenario } & \multirow{2}{*}{ No. } & \multirow{2}{*}{ Ship name } & \multirow{2}{*}{ Total day } & \multirow{2}{*}{ USD/day } & \multicolumn{2}{|c|}{ Total charter rate } \\
\hline & & & & & In USD & In IDR \\
\hline \multirow{3}{*}{3} & 1 & ASIAN GAS & \multirow{3}{*}{1825} & $\$ 4,950$ & $\$ 9,033,750$ & IDR $125,569,129,000.00$ \\
\hline & 2 & GAS PATRA 1 & & $\$ 6,450$ & $\$ 11,771,250$ & IDR $163,620,375,000.00$ \\
\hline & 3 & GAS ARAR & & $\$ 4,975$ & $\$ 9,079,375$ & IDR $126,203,312,500.00$ \\
\hline
\end{tabular}

TABLE 9.

Total Cost Calculation Port Charges LAMPung Port Scheme

\begin{tabular}{|c|c|c|c|c|c|c|c|}
\hline \multirow[b]{2}{*}{ Scenario } & \multirow[b]{2}{*}{ No. } & \multirow[b]{2}{*}{ Ship name } & \multirow[b]{2}{*}{ Port charges } & \multicolumn{2}{|c|}{ Arrival frequency } & \multicolumn{2}{|c|}{ Total cost port charges } \\
\hline & & & & Loading port & $\begin{array}{c}\text { Discharging } \\
\text { port }\end{array}$ & In USD & In IDR \\
\hline 3 & 1 & ASIAN GAS & $\$ 2,200$ & 207 & 206 & $\$ 908,600$ & IDR $12,629,540,000$ \\
\hline & 2 & GAS PATRA 1 & $\$ 2,200$ & 129 & 128 & $\$ 565,400$ & IDR 7,859,060,000 \\
\hline & 3 & GAS ARAR & $\$ 2,200$ & 187 & 186 & $\$ 820,600$ & IDR $11,406,340,000$ \\
\hline
\end{tabular}

TABLE 10.

TOTAL OPERATIONAL SHIP LAMPUNG PORT SCHEME

\begin{tabular}{lccc}
\hline \multicolumn{1}{c}{ Ship name } & \multicolumn{3}{c}{ Scenario 3 } \\
\cline { 2 - 4 } & Bunker cost & Operation cost & Charter rate \\
\hline ASIAN GAS & IDR 23,619,435,517 & IDR 12,629,540,000 & IDR 125,569,125,000 \\
\hline GAS PATRA 1 & IDR 24,892,555,593 & IDR 7,859,060,000 & IDR 163,620,375,000 \\
\hline GAS ARAR & IDR 25,628,991,695 & IDR 1,406,340,000 & IDR 126,203,312,500 \\
\hline
\end{tabular}




\section{CONCLUSION}

From the research on modeling the distribution of LPG vessels PT. Pertamina to meet the LPG supply chain in western Indonesia using discrete simulation, obtained several conclusions, among others:

1. There are several activities and conditions that affect the pattern of distribution of LPG vessels in this study, among which the ship's speed when carrying cargo or ballast LPG, the speed of the ship when at sea or when approaching the port, the pump speed when used loading or unloading.

2. Based on the results of the simulation has been done to meet increased demand, which is increasing in each depot, there are some things that can be done is to build scenarios with variations in the number and size of ships in operation.

TABLE 11

SYSTEM VARIATION

\begin{tabular}{cc}
\hline Decision variable & Respon variable \\
\hline Quantity vessel & Frequence distribution \\
\hline Capacity vessel & Utility vessel \\
\hline
\end{tabular}

From the analysis of simulation results, there is a scenario that managed to meet the increasing needs for each depot and also has a vessel operating expenses are the most economical. Here are the results of analysis per each depot scheme:

\section{A. Pangkalan Susu Port Scheme}

In this scheme the issues raised is the need of 2 million MT, scenario improvement $4^{\text {th }}$ has a higher utility value and results expressed may supply Pangkalan Susu Depot demand for 2.01 million Metric Tons by the utility value of each ship can be seen in Table 12 .

\section{B. Lampung Port Scheme}

In this scheme the issues raised which require 825,000 MT. Scenario improvement $4^{\text {th }}$ has a higher utility value.
In this scenario, the configuration of the ship amounted to 2 boats, the result otherwise be able to supply the needs of Pangkalan Susu Depot demand of 820 thousand Metric Ton. And utility value of each ship can be seen in Table 13.

\section{Tanjung Priuk Port Scheme}

In this scheme the issues raised which require 4.7 million MT. Scenario Improvement $1^{\text {st }}$ has a higher utility value and In this scenario, the configuration of the ship consists of 3 ships, the results expressed able to supply the needs of Pangkalan Susu Depot demand by 4.71 million Metric Tons. And utility value of each ship can be seen in Table 14 .

TABLE 12

Utilization VALUE of SCENARIO 4TH OF PANGKALAN SUSU PORT SCHEME

\begin{tabular}{ccccc}
\hline No. & Ship name & Capacity (MT) & Number of trip & Utility value \\
\hline 1 & Sinar Tarakan & 1500 & 272 & 0.71 \\
\hline 2 & Gas Attaka & 1950 & 262 & 0.63 \\
\hline 3 & Alia 1 & 970 & 268 & 0.6 \\
\hline 4 & Gas Patra II & 1700 & 264 & 0.67 \\
\hline 5 & Arjuna & 1400 & 268 & 0.612 \\
\hline
\end{tabular}

TABLE 13

Utilization VALUE OF SCENARIO 4TH OF LAMPUNG PORT SCHEME

\begin{tabular}{ccccc}
\hline No. & Ship name & Capacity (MT) & Number of trip & Utility value \\
\hline 1 & Symbio One & 1500 & 230 & 0.66 \\
\hline 2 & Arimbi & 2500 & 199 & 0.71 \\
\hline
\end{tabular}

TABLE 14

Utilization VAlue of Scenario 1St OF TANJUNG PRIUK PORT SCHEME

\begin{tabular}{ccccc}
\hline No. & Ship name & Capacity (MT) & Number of trip & Utility value \\
\hline 1 & Widuri & 9400 & 180 & 0.685 \\
\hline 2 & Apoda & 9700 & 177 & 0.689 \\
\hline 3 & Nusa Bintang & 6200 & 211 & 0.737
\end{tabular}

\section{REFERENCES}

[1] Dewan Energi Nasional, "Outlook Energi Indonesia 2014", Jakarta, 2014.

[2] Gasdom. "Rencana konversi minyak tanah ke LPG tahun 2009". Jakarta: Pertamina, 2008.

[3] Harrell, C., B.K. Ghosh and R.O. Bowden, Jr., "Simulation Using Promodel”, McGraw-Hill, Singapore, 2003.

[4] Wiralaksana, A. P. "Optimasi Penjadwalan Rute Pelayarann Kapal Distribusi LPG PT. Pertamina Berdasarkan Skenario Perubahan Komposisi, 30\% Propan - 70\% Butan", Surabaya: Jurusan Teknik Sistem Perkapalan ITS, 2010.

[5] Anggraini, Dystian. Optimasi Konfigurasi Jaringan Supply Chain Hulu Gas LPG $3 \mathrm{Kg}$ di Indonesia. Jurusan Teknik Industri. ITS, 2008.
[6] Kementerian ESDM, "Kajian Suplly Demand Energy", Jakarta, 2012.

[7] Novada, Indah. "Analisis Konsumsi dan Perilaku Masyarakat Terhadap Penggunaan Gas Elpiji”. Jurusan Teknik Industri. Universitas Sebelas Maret. Surakarta, 2011

[8] Rahmita, Kalim. "Studi Simulasi Angkutan Batubara Untuk Memenuhi Peningkatan Kebutuhan di PLTU Suralaya". Jurusan Teknik Sistem Perkapalan. Institut Teknologi Sepuluh Nopember. Surabaya, 2012.

[9] M. Mukhtasor, T. B. Musriyadi, I. S. Arief, and A. W. C. Saputra, "Horizontal Pendulum Performance Analysis with Multilevel Model Plate on Ocean Wave Electric Power Plant (PLTGL)," Int. J. Mar. Eng. Innov. Res., vol. 1, no. 2, Mar. 2017. 